\title{
A thematic and etymological glossary of aquatic and bird genera names in Iranian Bundahišm
}

\author{
Golnar Ghalekhani ${ }^{1 *}$ and Mahdi Khaksar ${ }^{2}$ \\ ${ }^{1}$ Department of Foreign Languages and Linguistics, College of Literature and Humanities, Shiraz \\ University, Shiraz, Iran \\ ${ }^{2}$ Department of Foreign Languages and Linguistics, College of Literature and Humanities, Shiraz \\ University, Shiraz, Iran
}

*Corresponding author: gghlekhani@rose.shirazu.ac.ir

Keywords: thematic and etymological glossary, Iranian Bundašin, animal genera, aquatic, bird

\begin{abstract}
The purpose of this study is to present a thematic and etymological glossary of aquatic and bird genera names which have been mentioned in Iranian Bundahišn. In this research, after arranging animal names in Persian alphabetic order in their respective genus, first the transliteration and transcription of animal names in middle Persian language are provided. Afterwards, the part of Bundahišn that contains the actual animal names and the relevant translations are mentioned. The etymology of every animal name is described by considering the morphemic source. Finally, mention is made of the mythology connected to the animal and the animal category in Iranian Bundahišn (if available), and the way in which the words have changed from Old Persian up to now. Changes in the name of every animal from the ancient languages such as Indo-European, Sanskrit, Old Persian and Avestan to middle languages such as Pahlavi, Sogdian, Khotanese, and Chorasmian and how the name appears in new Iranian languages and dialects such as Behdini (Gabri), Kurdi, Baluchi and Yaghnobi are also referred to.
\end{abstract}

\section{INTRODUCTION}

Bundahišn, the most valuable and the most important book in Pahlavi, is a religious-historical book that consists of approximately 13000 words and since it incorporates a lot of information on the mythology and sciences related to the Pre-Islamic era, it may also be regarded as a kind of encyclopedia of the Pre-Islamic era. This book includes stories about creation, the battle of Hormozd (Ahura Mazda) and Ahriman, discussions on four eras of three thousand years, mythological and the real history of Iran from Pishdadian dynasty to the arrival of Arabs, as well as information regarding prediction of upcoming events, the end of the world, and the emergence of Saoshyant, doomsday and Tan e Pasin (resurrection plus incarnation). This book, also, includes explanations concerning astronomy, astrology, calendar, zoology and the geology of the Pre-Islamic era.

Bundahišn may be regarded as the most important source to get access to Pahlavi vocabulary since it includes different subjects. The original title of the book was n "Zand Agahi"; however, since the first subject discussed in the book was the creation of the world, the name Bundahišn was assigned to it later on (Bahar, 1966 pp. 1-2). As for the etymology of the title of the book, the word Bundahišn consists of two parts: Bun originating from the Avestan word bunameaning "beginning" and dahišn the gerund of dādan meaning "creation" which is derived from $\sqrt{ } d \bar{a}$ meaning "making and creating" (Cheung, 2007 p. 45). Farnbagh Dadagi, the author of Bundahišn, is supposed to have lived in the late $3^{\text {rd }}$ century AH. Bahar, in the translation of Bundahišn, introduces the author of the book by saying that he was from the magi family who is related to Manuchehr Shahriar by thirty generations on the paternal side and thirty six generations on the maternal side (Bahar, 2011 p. 6).

There are two versions of Bundahišn: one of them is the abridged version known as the Indian Bundahišn and the other is the full version which is named the Great Bundahišn or the Iranian Bundahišn. The Iranian Bundahišn is divided into 46 chapters which make the book more detailed and comprehensive than the Indian Bundahišn (Bahar, 1966 pp. 1-2). 
The first part of Bundahišn is about the beginning of creation, and the next parts are about physical creation, creation of the stars, how and why creatures are created for battle, Ahriman's invasion of creation, the hostility of the two skies, world horoscope, and the strive of the creatures against Ahriman. The ninth part of the book provides further information about creations and it is divided into chapters on the qualities of fields, mountains, seas, rivers, lakes, animals, people, women, the emergence of every genus, vegetation, lordship of people and sheep, and also the qualities of fire, dream, sounds, wind and rain, vermin and wolf genus.

The next parts of Bundahišn incorporate descriptions of religious year, magnitude of Minavian "heavenly" gods, evil of Ahriman and demons, anatomy of man resembling the world, leadership of countries, Činvat Peretum and the spirit of the ancients, the famous cities of Iranshahr and kings' palaces, edifices that kings created, doomsday and resurrection, genealogical tree of the kings, ancestry of the magi and the calendar of the Arabs in twelve thousand years. In sum, the issues presented in the book may be divided into three major categories: religious and mythical beliefs, geographical contents and historical subjects.

Regarding the topic of this study, there are detailed chapters in Bundahišn on animals and their subdivisions as follows:

1- Karde which is based on the kind of animal: domestic or wild, and bird or aquatic.

2- Ayineh which is based on the shape of the feet in the animal: cloven hooves and one hoof animals, pedate animals, birds or fishes.

3- Genus that is a term used to refer to the minor subdivisions of every group of animals like dogs, horses and donkeys. (Bahar, 2011 p. 12)

Specifically speaking, chapters $7,13,15,22$, and 23 of Bundahišn are about the variety of creatures, useful quadrupeds, advent of creatures, harmful animals and species of wolves, respectively.

In this study the focus is to examine animal names mentioned in Bundahišn within the genera of aquatic animals and birds in an alphabetical order. In order to present the necessary information, the format of a thematic etymological dictionary is followed. A thematic etymological dictionary, as the name suggests, is a dictionary in which the words are primarily classified according to their themes and then the words are alphabetically arranged and further elaborated on according to their etymology. Regarding ancient Iran, the thematic dictionary is not unprecedented since two small samples of this type of dictionary have survived. One of them is oim êwag which is an Avestan thematic dictionary in Zoroastrian middle Persian and the other one is Pahlawīg dictionary which is about kings and difficult Zoroastrian middle Persian words.

\section{SIGNIFICANCE OF THE STUDY}

Texts related to the middle Persian language which have survived are little known but vast resources with regard to their content and remarkable vocabularies. In fact, after Dinkard, Bundahišn is the most important surviving text from Pahlavi literature. Thus it may be said to be a significant useful resource that may be used for etymological studies in the Persian language as well as other Iranian languages and dialects.

In this study, it has been attempted to compile a glossary which includes precise information about words related to aquatic animals and birds so that it may be used as a rich reference to check originally Persian words in the zoology of ancient Iran. This research gains further significance when it is noticed that, to the best of the researchers' knowledge, so far no such thematic glossary has ever been compiled in this area based on Bundahišn.

\section{OBJECTIVES OF THE STUDY}

The main objective of this study is to describe words related to aquatic animals and birds in Bundahišn in terms of their theme and etymology to compile a glossary in this regard. In fact, collecting all animal names existing in Pahlavi texts and studying their etymology is not possible in 
one article; therefore, the present study sought to describe these names in Bundahišn, which is regarded as an encyclopedia in its era.

It is worth mentioning that in this study we try to consider the trend of change in the names of the animals precisely from the ancient era to the middle era and from the middle era to the new era. In fact, showing the evolutionary course of word changes is one of the important objectives of the present study.

\section{METHOD OF THE STUDY}

The method used in this study is the library method in that each animal name mentioned in Bundahišn is written first based on the genus and Persian alphabetic order, then the meaning in English, and the transliteration, transcription, and a part of the text in which the word was originally used will be presented along with its translation. After that, the equivalents of animal names are presented in different languages where they are mentioned, respectively: first the Indo-European and Sanskrit and then Avestan, Old, middle, Parthian, Manichean, Pazand, Balkhi, Khwarizmi, Khotani, Saka (Buddhist, Manichaean, Christian) Persian languages and Balochi, Behdini, Kurdish and Yoghnobi dialect. It is attempted to choose the equivalent of each word in other languages from the authentic dictionary in that language, that is, for example, Indo-European: Pokorny (2007), Sanskrit: Mayrhofer (1986-1992-1997-2001), Avestan: Bartholomae (1961), and Old Persian: Hinz (1975) and Kent (1953). So the trend of change can be seen from the ancient era to the middle era and finally to the New Persian. Then in the section of word definition, with reference to the studies done earlier in this regard, different ideas regarding the word put forward by the scholars in the new and up-to-date references will be presented.

\section{LITERATURE REVIEW}

In relation to the publication, interpretation and translations of Pahlavi texts there are valuable dictionaries and various books in different languages by great scholars and researchers. Research in this field makes it necessary to use these texts, a number of which are reviewed below. For example, we can refer to translations of the whole of parts of the book by Duperron (1771) in French, West (1880) in English, and Modi (1901) in Gujarati. Furthermore, Anklesaria (1908) published the TD2 Bundahišn and the book was known as the most complete text in English. Bartholomae (1911) published a critical text of Bundahišn on the middle Iranian studies. Later on, Anklesaria (1956) transcribed and translated the great Iranian Bundahišn into English. More recently, Pakzad (2005), whose work includes Iranian Bundahišn transcription, wrote a critical text of Bundahišn.

Regarding research on different topics covered in Bundahišn, we may refer to the following examples. Nyberg (1928) focused on the theory of creation and Mazdean astronomy, Mackenzie (1964) investigated the topic of astronomy, and Asmussen (1970) worked on the fruits existing in Bundahišn.

As for the works more relevant to the topic of this study, i.e. animals in ancient Iran, there are some books and articles. Mahyar Nawabi (1976) published a series of articles in which he studied Babr e Baian (wild tiger) and its relation to Rustam's garment. Abdullahi (2002) published Animal dictionary in Persian literature in which he presented information about animals in ancient Iran based on the terminology of the words, the myths and beliefs about them, and their use in proverbs and adages as well as fiqh references. Jafari (2003) published texts related to the mythical information about horses. Kojani Hesari (2006) in an article studied mythical animals in Shahnameh. Vaheddoust \& Rabiei (2007) also studied the animals whose names can be found in Shahnameh. Ghaem \& Yahaghi's (2009) article focused upon different kinds of horses in Shahnameh. Tavaratani (2010) studied myths related to snakes. Hasandoust (2010) published the comparative-subject dictionary of new Iranian languages and dialects in two volumes in the first volume of which a part is designated to animals. Rezaii Bagh Bidi (2011) published The subject 
dictionary of Iranian ancient languages and one of the books in this series is about animal and human organs. Finally, Zonnubi (2012) wrote an etymological dictionary of mythical animals in Avesta as his thesis.

In spite of the great endeavors made to translate and study ancient texts and specifically Bundahišn, little attention has been paid to do a thematic etymological study of the animal names mentioned in the Bundahišn; therefore, the present study can be considered the first attempt in this regard.

\section{GLOSSARY}

In this section results of the study are presented in two sections: the first section provides elaboration on the animals in the aquatic genra and the second one on the bird genra. As mentioned before, the items in each section are alphabetically arranged and explained.

\subsection{Aquatic Genera}

\section{Asp abi (Hippopotamus) [SWSYA 'pyk'] asp ābig (Mackenzie, 2011 p. 31, 43)}

panĵm asb ̌̌aš sardag tāzīg ud pārsīg ud astar ud xar ud gōr ud asp ì ābīg abārīg asp sardag. (Pakzad, 2005 p.172)

The fifth horses are divided into six genera: the Arabic, the Persian, mule, donkey, zebra, hippopotamus and other genera (Bahar, 2011 p. 79).

Manichaean Parthian: nihang (Durkin- Meisternest, 2004 p. 242).

Middle Persian Manichaean: nihang (Durkin- Meisternest, 2004 p.242)

\section{Description:}

In Bundahišn hippopotamus is mentioned in the chapter related to the quality of animals. According to the animal division design in Bundahišn the hippopotamus is under the genus of horses and the family of Kharpayan (donkey feet) and the species of Chara Arzani and Garishak (wild and domestic).

\section{Udre (Otter, aquatic cat) ['wdlk'] udrag (Mackenzie, 2011:149)}

... ud udrag ud mušk-pad-rān ke az awešān dō sarfag sūrāg-hammoxtišn ... (Pakzad, 2005 p.172)

... And Udre and Moshkan-Be-Ran, are from two genera knowledgeable of holes ... (Bahar, 2011 p. 79).

Avestan: udra- (Bartholomae, 1904 p. 387).Old Persian: * udra- , *udraka-(Hinz, 1975 p. 241)

Description:

In Pahlavi texts this word is also recorded as following: samōr, âudra, âudrak, samūr, samūr siyā, simōr.

In Indo-European languages it is otter (Bahar, 2011 p.17).

The Otter in Bundahišn is divided into 8 genera.

3. mahi (fish) [m'hyk'] māhīg (Mackenzie, 2011 p.103)

dawazdahōm māhīg dād dah sardag (Pakzad, 2005 p. 175)

Twelfth the fish is created in ten genera (Bahar, 2011 p.79). 
abāz-danišnīh ì ān wazar rāy Ohrmazd dō māhīgān ī kar ānōh dād ēstēd (Pakzad, 2005 p. 267)

Hormozd in order to stop the toad has created two fish there (Bahar, 2011 p.100).

karmāhīg ì araz dāmān ì ābīgān rad ast. (Pakzad, 2005p. 223)

Catfish (KaraMahi) which is Araz is the lord of aquatic animals (Bahar, 2011 p.89).

Indo-European: krek-, krok- (Pokorny, 2007 p. 619) and kualCE (Pokorny, 2007 p. 635). Sanskrit: mátsya- (Hasandoust, 2010 p. 308). Avestan: masya-, kara-, vasī- (Bartholomae, 1904 p. 451, 1155, 1413). Old Persian: *kapa- (Hinz, 1975 p. 146). Parthian Manichaean: māsyāg (DurkinMeisternest, 2004 p. 227). Manichaean Middle Persian: māhīg (Durkin- Meisternest, 2004 p. 224) Pazand: māhig (Tafazzoli, 1969 p.209). Khwarizmi: kb (Hasandoust, 2010 p. 308). Khotani: kava, kara (Bailey, 1979 p. 53, 56). Buddhist Saka: kp- (Gharib, 1995 p. 191). Manichaean Saka: krw kpy, kp- (Gharib, 1995 p. 191, 194). Christian saka: kp- (Gharib, 1995 p. 191). Balochi: māhī(g) (Hasandoust, 2010 p. 308). Behdini: můsu (Hasandoust, 2010 p. 308). Kurdish: mâsî (Hasandoust, 2010 p. 308).

\section{Description:}

Many times, fish was introduced as a famous aquatic animal in Bundahišn, also the mythical KaraMahi was mentioned. Fish in Pahlavi is pronounced māhik and in Avestan texts there is no record of any combination or derivatives form this word. In Bundahišn it is stated that Ahriman created the toad for destruction and Ahura Mazda created the KaraMahi to stand against the toad.

...Hormozd in order to stop the toad created two KaraMahi there that are always moving around "Haoma"... and surely they are the fish nourishing from Minoo (heaven) they shall not be eaten, until Frashokereti they fight... the greatest of the creature that Hormozd has created is that fish ... (Bahar, 2011 p. 100).

Also In Bundahišn in the chapter related to the quality of animals, fish is known to be the twelfth group created (Abdullahi, 2002 p. 1046) and in the chapter related to Radan (the wise), KaraMahi was mentioned as the lord (Rad) of the aquatic animals: "KaraMahi, which is Araz, is the lord of the aquatic animals." (Bahar, 2011 p. 89).

\section{Description:}

The Avestan pronunciation of toad (wazagh) is close to the modern Persian one, vazaa- (vazaghe) and in Pahlavi language it is recorded in two forms: vak, vazag and surely vak is related to the pronunciation of bak (toad) which Logat-e fors considers this word to mean "toad". (Abdullahi, 2002 p. 1168).

Toad is a creature of Ahriman in Avesta and is regarded as an abominable animal. In Bundahišn, Khrafstaran (the vermin) are divided into three groups of aquatic, land, winged and among the aquatic group the toad is known to be the worst of all.

Toad from the aquatic and many headed dragon from the land animals... are the worst of all (Bahar, 2011 p. 98).

In the sixth and ninth part of Bundahišn, toad is mentioned. In the sixth part of the book it is stated that the toad is created in enmity to the earth. In the ninth part of Bundahišn we can see the following:

"It is said in the religion that white Haoma that is known as Gukaran tree has been grown in the Farakhkard Sea, the deep sea. And for Frashokereti (purgation) it is necessary, because eternity is from that. Ahriman, in opposition to him, has created a toad in that deep sea to destroy Haoma. To 
stop the toad, Hormozd created two KaraMahi there and they always move around Haoma. One of those KaraMahi always has its eyes on that toad.” (Bahar, 2011 p. 100).

\subsection{Bird Genera}

\section{Aluh (eagle) ['lwh] āluh (Mackenzie, 2011 p. 36)}

... ud āluh ud karkās ke dālman \{gowēd\} xwānēnd (Pakzad, 2005 p. 174)

... and Aluh and vulture which are known as dalman (Bahar, 2011 p. 79).

Avestan: ərəzi-fya-,saēna (Bartholomae, 1904 p. 354, 1548).

Sanskrit: rjipyá-, śyená- (Hasandoust, 2004 p. 48) and rjipyá- (Hasandoust, 2010 p. 260). Balochi: bānz (Hasandoust, 2010 p. 260). Kurdish: haĩo (Hasandoust, 2010 p. 260).

\section{Description:}

In Avesta the word saēna- means "eagle". Pourdavoud (1998) declared that syenÿ- in Sanskrit means the eagle whereas in Avesta saenna- means the eagle. Regarding this issue, Bahar, in the translation of Bundahišn, writes:

"If saéna- (means roc) in Avesta is equal to syéna- (means eagle) in Sanskrit then it is probable that roc was the same as eagle for Indians and Iranians." (Bahar, 2011 p. 171)

"The Persian dictionary in Pahlavi recorded the Pahlavi form of the eagle as dalman but considering the exact Bundahišn sentence ".... Vulture that is known to be dalman" one should accept that regarding the meaning of dalman considering it to mean the eagle is flawed. Other Pahlavi references translated aluh [āluh] from the Bundahišn sentence to the eagle and this word aluh is confirmed by later Persian dictionaries and references plus eagle is in fact the Arabic word which is known in Persian as aluh. (Abdullahi, 2002 p. 64).

Hasandoust believes that the root of this word is $V_{\text {pat }}$ (to fly) and the Sanskrit equivalent of this word is rijipyá- meaning the straight flight (rji- means straight in Sanskrit). He also relates this word to the Saka word āmata meaning nest and home which originates from $\sqrt{a} h$ meaning to sit and to inhabit. This word, also, was mentioned in the form of Apīv'Blos, Apsv'Pios which are proper nouns in Herodot and Kenzias (Hasandoust, 2004 pp. 48-49).

\section{Boof (owl) [bwk'/bwp] būg/büf (Mackenzie, 2011 p. 55)}

... garzag ud gurbag ud ān $\overline{1}$ parwar čiyon bug ... (Pakzad, 2005 p. 264)

.... Garze (snake) and cat and the one which flies like the owl.... (Bahar, 2011 p. 100).

murw $\overline{1}$ asōzušt kē murw $\overline{1}$ zōhrbarag ud wahman murw $\overline{1}$ šugazag-iz xwānēnd ... (Pakzad, 2006 pp. 275-276)

From Oshozosht bird that is Bahman bird or Zoorbarak bird, which they call owl (Bahar, $2011 \mathrm{p}$. 102).

Indo-European: bh(e)u- (Pokorny, 2007 pp. 97-98). Sanskrit: búkkati (Hasandoust, 2004 p. 218). Avestan: ašō.zušta- (Bartholomae, 1904 p. 259). Khwarizmi: cnc (Hasandoust, 2010 p. 218). Khotani: byūta- (Bailey, 1979 p. 309). Buddhist Saka: cywty (Gharib, 1995 p. 125). Balochi: gug (Hasandoust, 2010 p. 218). Zoroastrian: ququwa (Hasandoust, 2010 p. 218). Kurdish: pepû (Hasandoust, 2010 p. 218). 
Description:

According to Hasandoust, the word Boof is probably a derivative form of Indo-European root $\mathrm{b}(\mathrm{e}) \mathrm{u}$ - (beside bh(e)u-) meaning to make sound or to sing which are taken from the same root. In Avestan, bučahin- means howling and buxti- means howl or a long song/sound (see Hasandoust, 2004 p. 218). In Avestan the word ašo.zušta- is said to be the religious name for owl (Boof) and literally it meant "Asha" (righteousness and piousness). Abdullahi (2002) writes owl in Avestan is

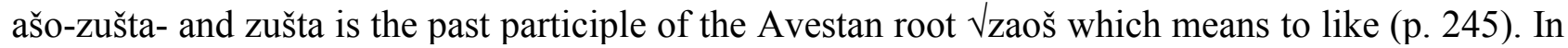
Bundahišn the importance and holiness of the owl in the ancient world is emphasized and it is believed that their most important religious book has been sung by it, and specific rites have been mentioned there as follows:

"About the Oshozosht bird which is the Zurabarak or Bahman bird which is called the owl it has been said that a part of Avesta is created in its language. When it sings, demons will flee and will not stay there. If the nail (taken) has not been charmed, demons and witches will take it and they will get angry and kill. This way that bird will take that nail, in case it is not charmed, take that to inhibit those demons and witches to do that. When it is charmed the owl will not eat it and demons cannot sin that way" (Bahar, 2011 p. 102).

\section{3. xorus (cock) [DYLKA] xrōs (Mackenzie, 2011 p. 164)}

... ud xrōs kē Parōdarš xwānēnd. (Pakzad, 2005 p. 174)

...the cock which is called Parvadarsh (Bahar, 2011 p. 79).

xrōs Pad hamēstārīh ī dēwān ud jādūgān dād ēstēd ud abāg sag ham-kar. (Pakzad, 2005 p. 282)

The cock is created to be the enemy of demons and witches and it cooperates with dogs (Bahar, 2011 p. 103).

az murwān $\overline{1}$ nar ān $\overline{1}$ xānag kunēd ud abganēd ēwāz xrōs čè ast Pad wēnišn 1 mardōmān abganēd. (Pakzad, 2005 p. 207)

From the male birds that lay eggs on earth the only one is the cock that does it in front of people (Bahar, 2011 p. 86).

Sanskrit: krkka-váku- (Mayrhofer, 1986 p. 388). Avestan: kahrka- (Bartholomae, 1904 p. 452). Old Persian: krkača- , krka- <cockerel> (Hinz, 1975 p. 152). Parthian Manichaean mury (DurkinMeisternest, 2004 p.234). Khwarizmi: nrk'm $\gamma$ (Hasandoust, 2010 p. 230). Khotani: krnga-, krriga (Bailey, 1979 p. 64 p. 66). Balochi: kurosk (Hasandoust, 2010 p. 230). Zoroastrian: oros(k) (Hasandoust, 2010 p. 230). Kurdish: kaīašêr (Hasandoust, 2010 p. 230).

Description:

The word cock is derived from $\sqrt{\mathrm{xraOS}}$ meaning to roar and cry and roaring and crying.

This word has changed into xrōs, xrōh in Pahlavi language.

In Avesta the words Paro.darӘs (Pahlavi: Parodarš) means the foreseer (Parvad = Para) meaning to see the dawn before anyone and tell about the dawn (Abdullahi, 2002: 339).

In Bundahišn, in the bird category, the cock is in one among the one hundred and ten genera. In the text of Bundahišn, also, the cock is introduced with its religious name Parodars and elsewhere it is introduced as Pes-daxsay (possessing the first sign or mark, which means the morning cry of the cock). 
The following text of Bundahišn suggests the holiness of this creature:

"The cock is created to oppose demons and witches and cooperates with dogs. Zoroaster says that the dog and the cock are cooperating with Soroush to destroy Doruj (a demon)" (Bahar, $2011 \mathrm{p}$. 103).

The interesting point about the cock in the text of Bundahišn is that the male bird lays eggs:

"From the male birds, the only one that lays eggs on earth is the cock which lays in front of people" (Bahar, 2011 p. 86).

"The cock ... lays eggs everyday secretly or openly... and just the cock is like this among the birds" (Bahar, 2011 p. 85).

\section{Simurgh [synmwlw] sēn-murw (Mackenzie, 2011 p.135)}

dahom murwān sad ud dah sardag \{u- š sēzdah sardag\} čiyōn sēn-murw ... (Pakzad, 2005 p.174)

The tenth, the birds are a hundred and ten genera: the thirteen genera of them (are) like Simurgh ... (Bahar, 2011 p.89).

az fradom murwān sēn $\overline{1}$ sē angurag dād nē ān rad ... (Pakzad, 2005 p. 223)

The first of birds was the Simurgh with three claws; it is not the lord of birds... (Bahar, 2011 p. 89).

Pazand: sīna-mrū (Rezaii Bagh Bidi, 2011 p. 133). Khwarizmi: symry (Rezaii Bagh Bidi, 2011 p. 133).

Description:

This word also emerges in Pahlavi texts in the form of sēn-murwag (Orian, 1371 p. 213). Nyberg believes the word mərOo.saēna refers to a big hunting bird like "eagle" thinks of it to be sēn and believes it means a miraculous eagle whose nest is on Vispubish Tree and the fruit of that tree is all kinds of cures (Nyberg, 2003 p. 175). But the mentioned word in song (yasht) 13 canto 97 meant a pious man (Zonnubi, 2012 p. 43).

Simurgh can be found in part 9 of Bundahišn belonging to the hundred and ten genera of the birds. Also in the chapter related to the lordship of people and sheep, the three clawed Simurgh is named as the first bird though it is not the lord (Rad) of the birds:

"The first of the birds was the three clawed Simurgh; it is not the lord of the birds because Karshift bird is the lord, the bird brought the religion Vara Jamkard (enclosure)." (Bahar, 2011 p. 89).

\section{Shabkoor (bat) [šwb'k'] šawāg (Mackenzie, 2011 p. 141)}

yazdahōm šawāg. az awēšān dō hēnd kē sir dārēnd ud Pad Pestān waččag Parwarēnd sen-murw ud sa šawag. (Pakzad, 2005 p. 174 p. 175)

The eleventh is Shabkoor. Two kinds exist which have milk and feed their babies with their breasts: Simurgh and Shabkoor (Bahar, 2011 p. 79).

čiyōn gowēd kū šawāg pad sē sardag dād ēstēd sag ud murw ud mušk (Pakzad, 2005 p. 175)

It is said that Shabkoor is created resembling these three genera: dog, bird (hen) and mouse (Bahar, 2011 p. 79). 
... ud ān-iz ke parr dārēd ciyōn šawag (Pakzad, 2005 p. 192)

... that it also has feathers like Shabkoor (Bahar, 2011 p. 83).

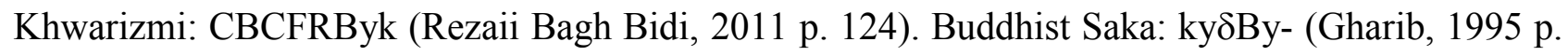
202). Balochi: čallatuk (Hasandoust, 2010 p. 232)

Description:

This word is also found in the Zoroastrian middle Persian in these forms: savbāg, šavāg and also Farah Vashi named it as šawāk, šapākparr (Farah Vashi, 1979 p. 205) and Tavusi has called it šabāgpar (Tavusi, 1986 p. 203) In Bundahišn the bat is in the category of birds and somewhere else it is known to be from the 25 races rooting from Kiumarth:

... Overall 25 kinds (of people) were from Kiumarth's race like from the land or water... the one which has feathers like Shabkoor (Bahar, 2011 p. 83).

\section{Ghaghom (Stoat) [k'kwm] kākom (Mackenzie, 2011 p. 96) (see otter, too)}

... ud kākom ud kākom ̄̄ spēd ud abārīg rasūg sardag. (Pakzad, 2005 p. 173)

.... and Ghaghom and the white Ghaghom and other kind of weasels (Bahar, 2011 p.79).

fradōm az rāsūgōn kākom ̄̄ spēd brēhēnīd ōy ast rasūgān rad.(Pakzad, 2005 p. 223)

Of weasels, the first one created was the white Ghaghom, it is the lord of weasels (Bahar, $2011 \mathrm{p}$. 89).

čigōn gowēd ku kākom 1 spēd kē ō hanjaman ī Amahrāspandān be mad. (Pakzad, 2005 p. 223)

It is said that the white Ghaghom (is the one) that entered Amesha Spenta's company (Bahar, 2011 p.89).

Khwarizmi: K'BS (Rezaii Bagh Bidi, 2011 p. 139).

Description:

Ghaghom is in the category of otters and is a creature like weasels. In Pahlavi texts it is also found in the following forms: kāgom, kākomag, kāgōm spēd, kākūmak, kāgumag. In Bundahišn, also, the white Ghaghom (kākom $\overline{1}$ spēd) has been mentioned as one of the eight genera of otters. The white weasel (the white Ghaghom) is regarded to be the lord (Rad) of weasels in the chapter related to the lordship of people and sheep:

"The white Ghaghom was created as the first of weasels; it is the lord of weasels." (Bahar, $2011 \mathrm{p}$. 89).

Also in this chapter the white Ghaghom is regarded as a creature entering Amesha Spenta company:

"The white Ghaghom is the one which entered Amesha Spenta's company" (Bahar, 2011 p. 89).

\section{Kabk (Partridge) [kpk'] kabk (Mackenzie, 2011 p. 95)}

... ānōh kū wāng 1 k kabk be šawēd xānag 1 kabg be rawēd āb be gīrēd. (Pakzad, 2005 p.280)

Wherever the partridges are gone and no partridges are present, grasshoppers will increase (Bahar, 2011 p.103). 


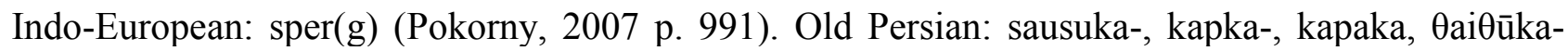
(Hinz, 1975 p. 81 p. 144 p. 146 p. 223). Khwarizmi: kbk (Hasandoust, 2010 p. 266). Khotani: ysara, ttere, ttatara- (Bailey, 1979 p. 122 p. 134 p. 447). Balochi: kabg (Hasandoust, 2010 p. 266). Zoroasrian: kawg (Hasandoust, 2010 p. 266). Kurdish: žeréš (Hasandoust, 2010 p. 266). Yaghnobi: zirêk (Hasandoust, 2010 p. 267).

Description: Partridge (Tihoo), also, is recorded in Zoroastrian middle Persian as kark, kabg, kapk and karg. In Bundahišn partridge is mentioned just once in the ninth part and the chapter concerning the way of creations in which the hostility of partridge to grasshopper is mentioned as an example of birds' hostility to the vermin:

"From wherever the partridges are gone and no partridges are present the grasshoppers will increase. To summarize, every wild animal and birds and fishes each of them is created to the enmity of the vermin." (Bahar, 2011 p. 103).

\section{Kaboutar (dove, pigeon) [kpwt'] kabōd (Mackenzie, 2011 p. 95)}

... ka ō nišēm $\overline{1}$ kabōd riyēd pillag-mār ̄̄ kūk aziš hambūsēd ... (Pakzad, 2005 p. 99)

... if a pigeon defecates on earth, Pile Mar Kook will be produced out of it... (Bahar, 2011 p. 99)

Old Persian: kaputī-, kaputa- (Hinz, 1975 p. 147). Manichaean middle Persian: kabōttar (DurkinMeisternest, 2004 p. 203). Khwarizmi: kbwd (Hasandoust, 2010 p.268). Khotani: korak,,, aṣðaa-, așș,naka (Bailey, 1979 p.12 p. 65). Buddhist Saka: kp'wt'ych (Gharib, 1995 p.191). Christian Saka: qwpwtyc, qpwtyc (Gharib, 1995 p.192 p. 200). Balochi: kabotar, kapot (Hasandoust, 2010 p. 268). Zoroastrian: kutār, kuptār (Hasandoust, 2010 p. 267). Kurdish: kôtā (Hasandoust, 2010 p.268). Yaghnobi: kapūča (Hasandoust, 2010 p. 269).

\section{Description:}

The word pigeon is also recorded in Zoroastrian middle Persian as kabūtar, kabūd, kapōtar and kabōtar.

"Kaftar and Kabtar meaning pigeon and the Pahlavi form of the word kapotar roots from Kabood meaning blue. In the footnotes of Borhan Ghate it is mentioned that there is arelationship between the word Kabootar (pigeon) and Kabood (color blue): "Kabutar (pigeon) is derived from Kabood (blue) of the ancient Indian kapōta-“" (Abdullahi, 2002 p.751).

The word Kabootar is only mentioned once in Bundahišn and it is in the ninth part and the chapter related to the way of creations in where explanations about Kasgin fly are available:

About the Kasgin fly it is said that... if it defecates on the Perch of a pigeon, Pile Mar Kook will be produced..." (Bahar. 2011 p. 99).

\section{9. karkas, dalman (Vulture) karkās [klk'a] (Mackenzie, 2011 p.98)}

... ud alūh ud karkās ke dālman \{gowēd\} xwānēnd (Pakzad. 2005 p. 174)

And aluh (eagle) and vulture are known as dalman (Bahar, 2011 p. 79)

karkas $\overline{1}$ zarmān menišn $\overline{1}$ ast dālman nasā xwarišnīh rāy dād.(Pakzad, 2005 p. 278)

Piri Andish vulture, which is dalman, is created to eat corpse (Bahar, 2011: 103).

dālman rāy gōwēd ku az ān $\overline{1}$ burztar-iz parwāz ka mušt masāy gōšt pad zamīg ast wēnēd u-š boy $\overline{1}$ mušk azēr $\overline{1}$ parrag dād ēstēd kū agar pad nasā xwardan gand $\overline{1}$ nasā ōšārēd sar azēr $\overline{1}$ parr abāz barēd ud abāz āsayēd (Pakzad, 2005 p. 281) 
About dalman it is said that it can see a little piece of meat on the earth when it flies and soars and it has musk under its feathers and when the stink of corpses (rotten meats) bothers it, it uses the musk under its feathers to relieve.... (Bahar, 2011 p. 103).

Khwarizmi: krkys (Hasandoust, 2010 p. 270). Khotani: uysgana-, aysgana (Bailey, 1979 p. 6 p. 38 ). Saka: crks (Gharib, 1995 p. 128) Buddhist Saka: crks (Gharib, 1995 p. 128). Manichaean Saka: crks (Gharib, 1995 p. 128). Zoroastrian: Karkas (Hasandoust, 2010 p. 270). Kurdish: dōl (Hasandoust, 2010 p. 270).

\section{Description:}

The Avestan pronunciation of vulture is kahrkāsa- and about this word it is said that it is a combination of kahrka- (Kark=bird) and Asa- (eater) and the whole word means bird eater (Abdullahi, 2002 p. 769) the root of this word is $\sqrt{\mathrm{as}}$ meaning to eat (see Cheung, 2007 p. 168).

Vulture has also been found in Pahlavi texts as dālman and kasgās.

In Bundahišn, vulture is in the birds' group and it has been explicitly named Dalman. “...vulture which is known as Dalman" (Bahar, 2011 p. 79).

Somewhere else, when Mashya and Mashyana slayed a sheep to eat for the first time, they threw a piece of meat as a sign of gratitude to God into the sky:

... And threw a piece of meat into the sky ... the vulture bird flied but couldn't get it (Bahar, 2011 p. 87)

Somewhere else in Bundahišn, it is also mentioned:

... and the odor of musk under its feathers is created so that if the stink of carrion bothers it while eating, it can inhale it under its feathers and relieves... (Bahar, 2011 p. 103).

In the ninth part of Bundahišn in the chapter related to the way of creations, the scavenging of the vulture (dalman) is mentioned and the bird is named Piri Andish vulture:

"Piri Andish vulture which is called dalman is created to eat the dead/corpse." (Bahar, 2011 p. 103).

\section{0. kalagh (crow) [wl'g] warā (Mackenzie, 2011 p. 153)}

... ud warā \{ud poš ud xrōs ke parōdarš xwānēnd ud\} kulang.(Pakzad, 2005 p.174)

Crow and Posh (owl), cock which is known as Parvardarsh (cock) and Kolang (a bird). (Bahar, 2011 p. 79).

Indo-European: ames-* (Pokorny, 2007 p. 35 p. 36). Avestan: vārOngan (Rezaii Bagh Bidi, 2011 p. 144). Khwarizmi: we'a (Hasandoust, 2010 p. 276). Khotani: șṣund, șāṃd, ramdām (Bailey, 1979

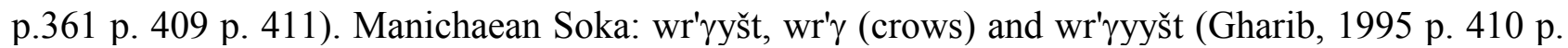
410 p. 410). Balochi: zār (Hasandoust, 2010 p. 276). Zoroastrian: kolāq (Hasandoust, 2010 p.276). Kurdish: qẫ̂âu (Hasandoust, 2010 p. 276).

Description:

In Bundahišn, crow is in the genus of birds and is described as to be scavenger and infective:

"Crow and Sargar (starling which feeds on carrion) which feeds on Taurotragus and Bezoar Ibex, and also other vermin..." (Bahar, 2011 p. 103). 
About the wit and genius of this bird it is also mentioned that:

... Wild birds are the enemies of the vermin and witches. It is also said that all birds are witty/clever. And crow is the wisest of all (Bahar, 2011 p. 102).

\section{CONCLUSION}

The results of investigation of the animal names belonging to the aquatic and bird genera mentioned in Iranian Bundahišn which were presented in detail above show that names of some birds have not changed from middle Persian to modern Persian. As an example, āluh (eagle) is currently used by Persian speakers (especially in some cities like Isfahan). Another example is būf (owl) which is still used by many Persian speakers; however, the bird used to be considered holy and significant whereas in new Persian the bird generally signifies bad omen. Some other names of birds which were employed in middle Persian are also used in new Persian, though with some minor changes in pronunciation. xorus (cock), sēn-murw (simurgh), karkās (vulture), warā (crow), kabōd (dove, pigeon), Kabk (Partridge) and kākom (Stoat) illustrate the point. Among the aquatic animals, asp ābig (hippopotamus), udrag (Otter, aquatic cat), māhīg (fish), waza (toad) underwent no major phonological change from middle Persian to new Persian, though regarding dutifulness, waza (toad) used to be considered a creature of Ahriman in Avesta and thus an abominable animal whereas among the different kinds of fish, KaraMahi, which is no more used in new Persian, was mythically regarded as the lord of the aquatic animals.

Finally, we may suggest the following as topics to be investigated in further studies in this area: whether the classification of animals in other middle era books like Zadsparm anthology corresponds with the classification of Bundahišn or not; if not, what changes in which genera of animals have occurred; whether the animals mentioned in this study have any counterparts in other civilizations and cultures; what roles the animals named in Bundahišn have in Shahnameh and later texts? What will the classification of other animal genera show?

\section{References}

[1] Anklesaria, B. T. (1908). The Bundahishn. Being a Facsimile of the TD Manuscript. No. 2, Bombay.

[2] Anklesaria, B.T. (1956). Zand-Akasih, Iranian or Greater Bundahisn. Transliteration and Translation in English. Bombay.

[3] Asmussen, J.P. (1970). The list of fruits in the Bundahis, in W. B. Henning memorial volume, 14- 19.

[4] Bahar, M. (1345 H/1966). Vazhe-nameye Bundahishn [Bundahishn Dictionary]. Tehran: Bonyad-e Farhang-e Iran.

[5] Bahar, M. (1345 H/1996). Pazhuheshi dar Asatire Iran [A Study of Iranian Myths]. Vols.1 \& 2, Tehran: Agah.

[6] Bahar, M. (1390H/2011). Bundahishn Faranbaq Dadagi [Bundahishn Faranba Dadagi]. Tehran: Toos.

[7] Bailey, H.W. (1979). Dictionary of khotan saka. Cambridge.

[8] Bartholomae, Ch. (1961). Altiranisches worterbuch. strassburg:verlag von karl J.trubner

[9] Bartholomae, Ch. (1911). "Mitteliranische Studien, Il". Zur Textkritisch des Bundahish", ZDMG.

[10] Cheung, J. (2007). Etymological dictionary of the Iranian verb. Leiden-Boston: Brill. 
[11] de Blois, F. \& Sims-Williams, N. (eds.) (2007). Dictionary of Manichaean texts in Chinese. Belgium: Brepols.

[12] Duperron, A. H. (1771). Le Zend-Avesta. 3 volumes, Paris.

[13] Durkin-Meisternest, D. (2004) Dictionary of Manichean Middle Persian \& Parthian. School of Orient and African Studies: University of London.

[14] Ghaemi, F. \& Yahaghi, M. J. (1388 H/2009). Asb, por tekrartarin namadineye janevari dar Shahnameh va naghshe an dar takamole kohan olguye ghahremanan [Horse, the most frequent animal imagery in Shahnameh and its role in the evolution of archetypical heroes]. Faslnameye zaban va adabe Farsi [Periodical of Persian Language and Literature], 42, 9-26.

[15] Hasandoust, M. (1383 H/2004). Farhange risheh shenakhtiye zabane Farsi (jelde 1). [Etymological dictionary of Persian Language, vol. 1]. Tehran: Nashre Asar.

[16] Hasandoust, M. (1389 H/2010). Farhange tatbighi- mozuiye zabanha $v$ guyeshhaye Iranie no (Jelde 2) [Comparative-Thematic Dictionary of Modern Persian Languages and Dialects, Vol. 2]. Tehran: Nashre Asar.

[17] Hinz, W. (1975). Altiranisches sprachgut der nebenuberlieferungen (gottinger orientforschungen, reihe3, iranica,band 3). Wiesbaden: Harrassowitz

[18] Jafari, M. (1382 H/2003). Asb va baran sazi dar asatire Irane bastan [Creating horse and rain in Ancient Iranian Myths]. Motale'ate Irani [Journal of the Iranian Studies], 4, 53-60.

[19] Kent, R. G. (1953). Old Persian: Grammar, Texts, Lexicon, New Haven/Connecticut: American Oriental Society.

[20] Kojani Hesari, H. (1385 H/2006). Mojudate mohum dar shahnameh [Fantastic Creatures in Shahnameh]. Mahnameye Hafez [Journal of Hafez], 27, 73-83.

[21] Mackenzie, D. N. (1964). Zoroastrian Astrology in the Bundahisn, BSOAS, 27, 511- 529.

[22] MacKenzie, D. N. (2011). Concise Dictionary of Pahlavi. Trans. Mahshid Mir Fakhraei. Tehran: Institute of Humanities and Cultural Studies.

[23] Mahyar Nawabi, Y. (1355 H/1976). Majmueye mghalat (jelde 1) [Collection of Papers, Vol. 1]. Shiraz: Shiraz University.

[24] Mayrhofer, M. (1986-1992-1997-2001). Etymologisches worterbuch des altindoarischen. 4bd. Heidelberg: Carl Winter.

[25] Modi, J. J. (1901). Bundahishn. Text, transliteration and translation in Gujarati, introduction and notes. Bombay.

[26] Nyberg, H. S. (1928). Ein Hymnus auf Zervan in Bundahis, ZDMG, 82, 217- 235.

[27] Nyberg, H. S. (2003). A Manual of Pahlavi, 2 vols. Tehran: Asatir.

[28] Pakzad, F. (1384 H/2005). Bundahishn (jelde 2): matne enteghadi [Bundahishn, vol. 2: Critical Text]. Tehran: Markaze dayeratolmaarif bozorge Eslami.

[29] Pokorny, J. (2007). Indogermanisches Etymologisches worterbuch. 2vol. bern- stuttgurt.

[30] Pourdavoud, E. (1377H/1998). Yashtha, jelde 2 [Yashts. vol. 2]. Tehran: Asatir.

[31] Rezaii Bagh Bidi, H. (1390 H/2011). Vazhe nameye mozuiye zabanhaye bastaniye Iran, badane ensan va janevaran, namhaye janevaran (jelde 1) [Thematic Dictionary of Ancient Iranian Languages, bodies of human beings and animals, animal names], Tehran: Nashre Asar.

[32] Tavaratani, Z. (1389 H/2010). Adabiyate tatbighi mar va kaj [Comparative Literature of Snake and Pine]. Tehran: Behjat. 
[33] Vaheddoust, M. \& Rabiei, F. (1386 H/2007). Avatefe heyvani dar shahnameh [Animal Emotions in Shahnameh]. Motale'ate Irani [Journal of the Iranian Studies], 12, 197-214.

[34] West, E. W. (1880). The Bundahish, Pahlavi Texts. Oxford.

[35] Zonnubi, R. (1391 H/2012). Farhange rishehshenakhtiye janevarane asatirieye Avesta va bazjaste an dar motune Farsie miyaneiye ketabi va Shahname [Etymological Dictionary of Mythological Animals in Avesta with Examination in middle-Persian Texts and Books and Shahnameh.] M.A. dissertation. Shiraz: Shiraz University. 